за въвеждането на обучението по Обща медицина в МФ, Стара Загора. Като член на екип преподаватели, подготвени във Великобритания, Полша и България и локален експерт по образование в рамките на съответния проект по програма PHARE (1996-1998 г.), гл. ас. д-р Св. Димитрова участва активно в изработването на учебните програми и в студентското обучение по обща медицина.

От 2004 г. в Медицинския факултет се провежда обучение на студенти по специалност „Управление на здравните грижи“. Основен принос за развитието на новата специалност имат сьтрудниците на катедрата с изключителната подкрепа на изтькнати специалисти в областта на социалната медицина от Факултет по обществено здраве, МУ - София под ръководството на проф. д-р Цекомир Воденичаров, дмн. От този момент и до сега тази подкрепа е значителна. Следва да подчертаем приноса на доц. д-р Кирил Кирилов, дм. за обучението по дисциплината „Основи на управлението в здравеопазването“с бакалаври и магистри; на доц. Мирчо Вуков, дм от НЦОЗ - София за развитието на преподаването по дисциплината „Медицинска информатика и биостатистика“. Ценно е сътрудничеството и подкрепата на доц. д-р Невяна Фесчиева, дм - ФОЗ, МУ - Варна като преподавател по „Епидемиология на здравето“ и като научен ръководител на докторанти в катедрата. Проф. Димитър Костов, дсн има принос за развитието на преподаването по дисциплината „Икономика на здравеопазването“. Проф. д-р Асен Петков, дм и проф. д-р Станка Маркова, дм оказват съществена подкрепа за преподаването по Управление на здравните грижи.

Към настоящия момент в катедрата се провежда обучение на студенти от всички специалности в направленията Медицина, Здравни грижи и Обществено здраве в Медицинския факултет, Тракийски университет - Стара Загора.

Сътрудниците на катедрата участват в следдипломното обучение на специализанти по Социална медицина и Обща медицина и активно се включват в различните форми на продължаващо обучение, осъществявани в Медицински факултет.

Успоредно с учебно-преподавателската, от самото основаване на катедрата се развива и научно-изследователската дейност. Областите на научен интерес на академичния състав са широкообхватни и насочени към актуални проблеми на общественото здраве с приноси, имащи важни приложни аспекти. Основните области на научноизследователска дейност бихме обобщили като:

- здравно състояние на населението: исторически поглед; индикатори; състояние и тенденции;

- предизвикателства пред съвременната медицинска етика: етични аспекти на сексуалното и репродуктивно здраве и права̀; етика на аборта; медико-етични проблеми, свързани със взаимоотношенията лекар-пациент; информирано съгласие на пациента; права̀ на пациента;

- медицинско образование: иновации; оценка качество на обучението;

- здравнополитически проблеми в условията на здравна реформа: актуални проблеми на общата медицинска практика; управление на човешките ресурси; майчино и детско здравеопазване;

- съвременна епидемиология;

- медицинска информатика и биостатистика;

- история на медицината.

Академичният състав на катедрата активно е участвал и продължава да работи по повече от 20 международни, национални и университетски научни проекти.

Кьм настоящия момент в катедрата се провежда последователен и непрекъснат процес на подготовка на докторанти по научните специалности „Социална медицина и организация на здравеопазването и фармацията“ и „Управление на здравните грижи“.

35-годишен период на развитие е основание за размисъл и равносметка на изминатия път, предизвикателствата и перспективите за бъдещето, както и повод да изразим признателността, благодарността, уважението и почитта към делото на нашите ръководители и учители, на които дължим това, което сме постигнали. Не бихме имали сегашния си облик, без подкрепата и сътрудничеството на колегиалната общност от университета и в страната, за което изразяваме дълбока благодарност. На тази подкрепа и сътрудничество разчитаме и занапред.

$$
* *
$$

\title{
Проф. Здравко Богданов на 90 години
}

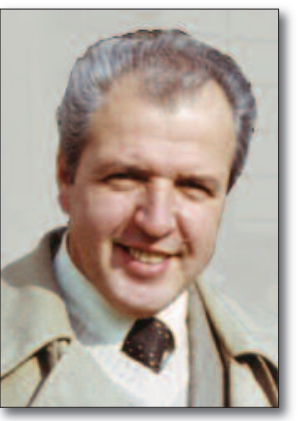

Редколегията на сп. “Социална медицина” честити юбилея на проф. Здравко Богданов по случай неговата 90-годишнина. Неговият дългогодишен професионален път е целенасочено отдаден на здравнодемографската статистика в нейния пълен цикъл - от изграждането на системата на събране на данни до систематизирането и анализирането на здравно-статистическата информация. В тази област той остави достойни дела като успешен учен, ръоводител и преподавател. В резултат на неговата упорита научнопроучвателна и приложна дейност са останали ценни анализи за здравното-демографското състояние на населението, които са използвани за вземането на решения от специалистите на Министерстото на здравеопазването и НОИ.

Защитава дисертация на тема „Основни причини за умиранията в България“. Избран е за ст.н.с. в НИСХОЗ под ръководството на проф. Тодор Захариев, където участва в осъществяването на най-голямото изследване до сега за здравното състояние на населението. Продължава работата си в ГИИЦ при МЗ. Самостоятелно извършва мащабно проучване за социално-медицинските аспекти на инвалидността в страната (1980-1986) и става доктор на медицинските науки. Работи като съветник в МЗ при министрите проф. Ив. Черноземски и доц. Н. Василев. Консултант е на Европейското бюро на СЗО в облаастта на здравно-демографската статистика. Преподавател е във Великотърновския универсиситет.

Проф. Здравко Богданов винаги е работел всеотдайно, с разбиране, толерантност, и усмивка към хората около него. Затова и днес остава обичан и уважаван от колегите, които се превърнаха в приятели. Бъди здрав и в добро настроение проф. Богданов! 